\title{
Effects of selected Palestinian plants on the in vitro exsheathment of the third stage larvae of gastrointestinal nematodes
}

Rana Majed Jamous ${ }^{1}$, Mohammed Saleem Ali-Shtayeh" ${ }^{*}$, Salam Yousef Abu-Zaitoun ${ }^{1}$, Alex Markovics² and Hassan Azaizeh ${ }^{3,4}$

\begin{abstract}
Background: Gastrointestinal parasites are one of the main restrictions to small ruminant production. Their pathological importance is primarily related to the major production losses, in quantity or quality, induced by the direct action of worms. Control of these parasites is based exclusively on the frequent use of anthelmintic drugs. However, the resistance to anthelmintics in worm populations after commercialisation of chemical drugs is now widespread. Therefore, there is a need to find new natural resources to ensure sustainable and effective treatment and control of these parasites. The aim of this study was to evaluate the anthelmintic activity, as minimum inhibitory concentration $\left(/ C_{50} \mathrm{mg} / \mathrm{mL}\right)$, of different plant extracts using larval exsheathment inhibition assay using a two-species but steady population of parasitic nematodes (ca. 20\% Teladorsagia circumcinta and 80\% Trichostrongylus colubriformis).

Results: The study showed that the ethanolic extracts of 22 out of the 48 plant extracts, obtained from 46 plant species, have an inhibitory effect $>50 \%$ (at concentrations of $100 \mathrm{mg} / \mathrm{mL}$ ) on the third stage larvae (L3) of the nematodes exhibited the strongest inhibition activity (94\%) with $/ C_{50}$ of $0.02 \mathrm{mg} / \mathrm{mL}$, where other members of the Rhamnaceae family have shown to possess strong anthelmintic activity (70-89\%).

Conclusions: Plant extracts are potential rich resources of anthelmintics to combat helminthic diseases. Our results suggest that extracts from Rhamnus elaternus, Epilobium hirsutum, Leucaena leucocephala and Rhamnus palaestinus have promising anthelmintic activity, with potential applications in animal therapeutics and feed.
\end{abstract}

Keywords: Anthelmintics, Exsheathment inhibition assay (LEIA), Medicinal plants, Polyphenolic compounds, Tannins, Palestinian flora

\section{Background}

Infections of the gastrointestinal tract of ruminants with parasitic nematodes represent a major pathology associated with outdoor production of sheep and goats worldwide [1-4]. Small ruminant are infected with the same prominent gastrointestinal parasites, which induce similar pathological symptoms and economic consequences [5]. Gastrointestinal nematodes are one of the main restrictions to sheep and goats production and may cause more than $20 \%$ loss for marketable products [6]. Their pathological importance is primarily related to the major production losses, in quantity or quality, induced by the

\footnotetext{
* Correspondence: msshtayeh@yahoo.com

${ }^{1}$ Biodiversity\& Environmental Research Center -BERC, Til, Nablus, Palestine Full list of author information is available at the end of the article
}

direct action of worms. However, other studies suggested that the host's immune-mediated response in grazing meat-breed lambs infected with T. colubriformis is the major component of production loss [7].

Control of gastrointestinal parasites is based exclusively on the frequent use of anthelmintic drugs. However, this apparently exclusive reliance on synthetic molecules is not sustainable and currently faces several limitations. The first one is the rapid development of resistance to anthelmintics in worm populations after commercialisation of chemical drugs and the occurrence, in some regions, of multi-resistant strains strongly challenges the control of these parasites with drugs nowadays [8-11]. Second, is the increased concern of consumers over drug residues in meat and milk 
products, and a potential risk for environmental contamination [12]. In the attempt to reduce the use of chemicals due to the concern about human health and environmental toxicology, new and safer food control approaches such as the use of natural compounds are nowadays being developed [13-15].

In vivo and in vitro studies have shown that plants containing secondary metabolites, such as tannins, sesquiterpene lactones and flavone glycosides, are a promising option for use in integrated nematode control in farm production systems [16-18]. Tannin-rich plant extracts have shown in vitro to prevent eggs hatching of nematodes, and hinder development, motility, and exsheathment of larvae [19-21]. In addition, feeding of goats and sheep with tanniferous plants has led to reduction of nematode egg excretion and worm burden [22-25]. Some differences in activity of the same tannin-rich resource might be depending on the tested parasite species.

Natural compounds from plants provide a remarkable opportunity in the search for new, effective and safe anthelmintic products [26-28]. In Palestine, medicinal plants have been reported to play a vital role in the treatment of many disease conditions in humans [29-32]. A recent study has revealed that around 140 medicinal plant species are still in use in traditional medicine in Palestine for the treatment of several livestock diseases including gastro-intestinal infections (causing diarrhea, colic, flatulence, constipation, digestive system, and anthelmintic) [33]. This research also showed the gastrointestinal disorders is the disease group in the study area that scored the highest informant consensus factor (ICF) value (0.90), followed by urinary, and reproductive disorders (0.89) [33]. However, these plants have not been experimentally evaluated for their anthelmintic activity to justify their use in the treatment of such infections. The current study was therefore aimed at: collection of potential local plant species from Palestine, extraction of the bioactive ingredients, and determining the total phenolic and tannin contents; evaluation of the anthelmintic activity of different plant extracts using larval exsheathment inhibition assay (LEIA), and determination of the minimum inhibitory activity $\left(I C_{50}\right)$ of the most active plants extracts.

\section{Methods}

Preparation of plant extracts for exsheathment tests.

Areal parts of 46 plant species belonging to 26 families were collected from open fields during the period from June 2015 to February 2016 from Palestine, where plant species were identified by Prof. M. S. Ali-Shtayeh from the Biodiversity and Environmental Research Center, BERC, Til Village, Nablus (Table 1). Voucher specimens are deposited in the Herbarium of BERC. Plant parts were dried at $50{ }^{\circ} \mathrm{C}$ for $24 \mathrm{~h}$, then ten grams from each dried material was grinded and incubated separately with $100 \mathrm{~mL}$ of $70 \%$ ethanol at $35{ }^{\circ} \mathrm{C}$ for $3 \mathrm{~h}$. The extracts were then filtered and dried using rotary evaporator at $50{ }^{\circ} \mathrm{C}$ to remove the ethanol followed by freeze drying. The powdered extracts were stored at $-20{ }^{\circ} \mathrm{C}$ for further analysis [18]. Extraction yield was calculated as g extract per $g$ dried matter (DM) of plant leaves.

\section{Determination of total phenolic content}

Total phenols in plant extracts were measured by a colorimetric assay following the Folin-Ciocalteu method [34]. In brief, $0.5 \mathrm{~mL}$ of each sample dissolved in methanol $(1 \mathrm{mg} / \mathrm{mL})$ was transferred to test tube and mixed with $2.5 \mathrm{~mL}$ of a 10 fold dilute Folin-Ciocalteu reagent and $2 \mathrm{~mL}$ of $7.5 \%$ sodium carbonate. The tubes were allowed to stand for $30 \mathrm{~min}$ at room temperature. Then the absorbance was recorded spectrometrically at $760 \mathrm{~nm}$ versus gallic acid as blank, and total phenolic content was expressed as mg gallic acid equivalent (GAE)/g dry weight. All samples were analyzed in three replicates.

\section{Determination of tannin contents}

Tannin content in each plant sample was measured using the polyvinylpyrrolidone (PVP) following the method described by Makkar et al. [35]. In brief, $0.5 \mathrm{~mL}$ of extract dissolved in methanol $(1 \mathrm{mg} / \mathrm{mL})$ was mixed with $0.5 \mathrm{~mL}(100 \mathrm{mg} / \mathrm{mL})$ of PVP, vortexed for few seconds, stand for $15 \mathrm{~min}$ at $4{ }^{\circ} \mathrm{C}$ and then centrifuged for $10 \mathrm{~min}$ at $3000 \mathrm{rpm}$. The non-tannin phenolics were determined in the clear supernatant in the same way as for total phenolic content. Total phenols in plant extracts were measured by the colorimetric assay following the Folin-Ciocalteu method as described above. Tannin content was calculated as the difference between total phenolic and non-tannin phenolic contents in the plant extracts.

\section{Larval exsheathment inhibition assays (LEIA)}

We used one donor goat that was parasitized by two nematode species, Teladorsagia circumcincta and Trichostrongylus colubriformis which are considered the main species at our region and usually found in the same animal. Species were identified as described by Van Wyk et al. [36]: their proportions in the suspension were steady throughout the year: 25,$75 ; 25,75 ; 20,80$; and $18,82 \%$; in winter, spring, summer, and fall, respectively. The LEIA assay was performed according to Bahuaud et al. [37]. The extracts were diluted in phosphate buffer solution (PBS), and the tested concentration was $1 \mathrm{mg} / \mathrm{mL}$. The test was performed on three replicate samples of each plant extract as well as of samples of the PBS solution, which served as a negative control. Approximately 200 L3 larvae $(150 \mu \mathrm{l})$ were mixed with 
Table 1 List of local flora analyzed for their exsheathment inhibition activity (LEIA) of the third stage larvae (L3) of a mixture of nematodes species

\begin{tabular}{|c|c|c|c|c|c|c|}
\hline $\begin{array}{l}\text { Scientific name (Family) } \\
\text { (Voucher specimen) }\end{array}$ & English Name & Plant part & $\begin{array}{l}\text { Total phenolic } \\
\text { content (GAE-mg/g) }\end{array}$ & $\begin{array}{l}\text { Tannins } \\
\text { (GAE-mg/g) }\end{array}$ & $\begin{array}{l}\text { \% Exsh. } \\
\text { inhibition } \\
(60 \mathrm{~min})\end{array}$ & $\begin{array}{l}\mathrm{IC} 50 \\
(\mathrm{mg} / \mathrm{mL})\end{array}$ \\
\hline $\begin{array}{l}\text { Rhamnus alaternus L. (Rhamnaceae) } \\
\text { (BERC-BX-C-0124) }\end{array}$ & Italian Buckthorn & Leaves & 68.1 & 46.35 & 94 & 0.02 \\
\hline $\begin{array}{l}\text { Rhamnus palaestinus Boiss. } \\
\text { (Rhamnaceae) (BERC-BX-C-0150) }\end{array}$ & Palestine Buckthorn & Leaves & 126.85 & 86.6 & 89 & 0.22 \\
\hline $\begin{array}{l}\text { Epilobium hirsutum L. (Onagraceae) } \\
\text { (BERC-BX-C-0250) }\end{array}$ & Great Willowherb & Leaves & 234.58 & 98.68 & 84 & 0.03 \\
\hline $\begin{array}{l}\text { Pistacia palaestina Boiss. } \\
\text { (Anacardiaceae) (BERC-BX-C-0010) }\end{array}$ & $\begin{array}{l}\text { Palestinian } \\
\text { Pistachio, Terebinth }\end{array}$ & Leaves & 121.63 & 58.93 & 84 & 0.50 \\
\hline $\begin{array}{l}\text { Laurus nobilis L. (Lauraceae) } \\
\text { (BERC-BX-C-0061) }\end{array}$ & Laurel, Sweet Bay & Leaves & 96.98 & 84.58 & 79 & 0.37 \\
\hline $\begin{array}{l}\text { Ziziphus sativa Gaetn. (Rhamnaceae) } \\
\text { (BERC-BX-C-0231) }\end{array}$ & Jujube & Leaves & 136.75 & 86.75 & 76 & 2.09 \\
\hline $\begin{array}{l}\text { Leucaena leucocephala (Lam.) } \\
\text { (Fabaceae) (BERC-BX-C-0264) }\end{array}$ & Leucaena & Leaves & 136.85 & 69.45 & 74 & 0.10 \\
\hline $\begin{array}{l}\text { Ziziphus spina-christi (L.) Desf. } \\
\text { (Rhamnaceae) (BERC-BX-C-0186) }\end{array}$ & $\begin{array}{l}\text { Christ's Thorn } \\
\text { Jujube }\end{array}$ & Leaves & 131.23 & 80.8 & 70 & 1.78 \\
\hline $\begin{array}{l}\text { Myrtus communis L. (Myrtaceae) } \\
\text { (BERC-BX-C-0051) }\end{array}$ & Common Myrtle & Leaves & 143.93 & 72.43 & 69 & 0.73 \\
\hline $\begin{array}{l}\text { Juglans regia L. (Juglandaceae) } \\
\text { (BERC-BX-C-0230) }\end{array}$ & Wallnut & Leaves & 90.58 & 42.55 & 68 & 1.23 \\
\hline $\begin{array}{l}\text { Sarcopoterium spinosum (L.) Spach. } \\
\text { (Rosaceae) (BERC-BX-C-0084) }\end{array}$ & Shruppy Barnet & Areal Parts & 215.93 & 103.48 & 65 & 0.37 \\
\hline $\begin{array}{l}\text { Dittrichia viscosa (L.) Greuter } \\
\text { (Asteraceae) (BERC-BX-C-0032) }\end{array}$ & Inula & Areal Parts & 162.8 & 73.4 & 63 & 0.40 \\
\hline $\begin{array}{l}\text { Rhus coriaria L. (Anacardiaceae) } \\
\text { (BERC-BX-C-0037) }\end{array}$ & Sicilian Sumach & Leaves & 256.78 & 19.68 & 62 & 0.30 \\
\hline $\begin{array}{l}\text { Olea europaea L. (Oleaceae) } \\
\text { (BERC-BX-C-0086) }\end{array}$ & Olives & Leaves & 80.43 & 47.6 & 60 & 2.02 \\
\hline $\begin{array}{l}\text { Acacia saligna (Labill.) Wendl. f. } \\
\text { (Mimosaceae) (BERC-BX-C-0042) }\end{array}$ & Blue-Leafed Wattle & Leaves & 154 & 74.9 & 55 & \\
\hline $\begin{array}{l}\text { Carthamus tenuis (Boiss. \& Blanche) } \\
\text { Bornm. (Asteraceae) (BERC-BX-C-0582) }\end{array}$ & Safflower & Areal Parts & 41.8 & 19.15 & 55 & \\
\hline $\begin{array}{l}\text { Satureja thymbra L. (Lamiaceae) } \\
\text { (BERC-BX-C-0206) }\end{array}$ & Summer Savory & Areal Parts & 97.45 & 31.4 & 53 & \\
\hline $\begin{array}{l}\text { Quercus calliprinos Webb (Fagaceae) } \\
\text { (BERC-BX-C-0016) }\end{array}$ & Kermes Oak & Leaves & 211.4 & 102.45 & 52 & \\
\hline $\begin{array}{l}\text { Cistus creticus L. (Cistaceae) } \\
\text { (BERC-BX-C-0157) }\end{array}$ & Cretan Rock Rose & Leaves & 219.85 & 84.65 & 51 & \\
\hline $\begin{array}{l}\text { Nicotiana glauca Graham (Solanaceae) } \\
\text { (BERC-BX-C-0193) }\end{array}$ & Tobacco Tree & Leaves & 31.2 & 11.15 & 50 & \\
\hline $\begin{array}{l}\text { Rosmarinus officinalis L. (Lamiaceae) } \\
\text { (BERC-BX-C-0018) }\end{array}$ & Rosemary & Areal Parts & 201.85 & 153.15 & 50 & \\
\hline Vitis vinifera L. (Vitaceae) (BERC-BX-C-0111) & Grape & Leaves & 81.93 & 51.05 & 50 & \\
\hline $\begin{array}{l}\text { Capparis spinosa L. (Capparaceae) } \\
\text { (BERC-BX-C-0106) }\end{array}$ & $\begin{array}{l}\text { Caper Bush, } \\
\text { Egyptian Caper }\end{array}$ & Fruits & 65.15 & 33 & 49 & \\
\hline $\begin{array}{l}\text { Eucalyptus camaldulensis Dehn. } \\
\text { (Myrtaceae) (BERC-BX-C-0039) }\end{array}$ & Red River Gum & Leaves & 197.23 & 131.05 & 49 & \\
\hline $\begin{array}{l}\text { Leucaena leucocephala (Lam.) (Fabaceae) } \\
\text { (BERC-BX-C-0264) }\end{array}$ & Leucaena & Fruits & 39.75 & 14.28 & 49 & \\
\hline Cupressus sempervirens L. (Cupressaceae) & Cypress & Leaves & 106.4 & 70.8 & 48 & \\
\hline
\end{tabular}


Table 1 List of local flora analyzed for their exsheathment inhibition activity (LEIA) of the third stage larvae (L3) of a mixture of nematodes species (Continued)

\begin{tabular}{|c|c|c|c|c|c|c|}
\hline $\begin{array}{l}\text { Scientific name (Family) } \\
\text { (Voucher specimen) }\end{array}$ & English Name & Plant part & $\begin{array}{l}\text { Total phenolic } \\
\text { content (GAE-mg/g) }\end{array}$ & $\begin{array}{l}\text { Tannins } \\
\text { (GAE-mg/g) }\end{array}$ & $\begin{array}{l}\% \text { Exsh. } \\
\text { inhibition } \\
\text { (60 min) }\end{array}$ & $\begin{array}{l}\mathrm{IC} 50 \\
(\mathrm{mg} / \mathrm{mL})\end{array}$ \\
\hline $\begin{array}{l}\text { Capparis spinosa L. (Capparaceae) } \\
\text { (BERC-BX-C-0106) }\end{array}$ & $\begin{array}{l}\text { Caper Bush, } \\
\text { Egyptian Caper }\end{array}$ & Leaves & 18.9 & 0.35 & 46 & \\
\hline $\begin{array}{l}\text { Solanum luteum Mill. (Solanaceae) } \\
\text { (BERC-BX-C-118) }\end{array}$ & Hairy Nightshade & Leaves & 40.2 & 11.65 & 45 & \\
\hline $\begin{array}{l}\text { Ceratonia siliqua L. (Caesalpiniaceae) } \\
\text { (BERC-BX-C-0137) }\end{array}$ & Carob & Leaves & 215.15 & 104.6 & 44 & \\
\hline $\begin{array}{l}\text { Heliotropium europaeum L. } \\
\text { (Boraginaceae) (BERC-BX-C-0161) }\end{array}$ & Common Heliotrope & Leaves & 26.15 & 8.2 & 43 & \\
\hline $\begin{array}{l}\text { Helianthemum syriacum (Jacq.) Dum } \\
\text { (Cistaceae) (BERC-BX-C-0482) }\end{array}$ & $\begin{array}{l}\text { Common } \\
\text { Rock-Rose }\end{array}$ & Areal Parts & 162.55 & 71.5 & 41 & \\
\hline $\begin{array}{l}\text { Atriplex halimus L. (Chenopodiaceae) } \\
\text { (BERC-BX-C-0014) }\end{array}$ & $\begin{array}{l}\text { Shruppy Saltbush, } \\
\text { Sea Orache }\end{array}$ & Leaves & 19.8 & 9.48 & 39 & \\
\hline $\begin{array}{l}\text { Salvia fruticosa Mill. (Lamiaceae) } \\
\text { (BERC-BX-C-0006) }\end{array}$ & $\begin{array}{l}\text { White Sage, } \\
\text { Common Sage }\end{array}$ & Leaves & 130.4 & 65.65 & 39 & \\
\hline $\begin{array}{l}\text { Teucrium capitatum L. (Lamiaceae) } \\
\text { (BERC-BX-C-0167) }\end{array}$ & Cat Thyme & Areal Parts & 60.18 & 28.08 & 37 & \\
\hline $\begin{array}{l}\text { Pinus halepensis Mill. (Pinaceae) } \\
\text { (BERC-BX-C-0015) }\end{array}$ & Aleppo Pine & Leaves & 81.08 & 53.93 & 36 & \\
\hline $\begin{array}{l}\text { Rubus sanctus Schreb. (Rosaceae) } \\
\text { (BERC-BX-C-0113) }\end{array}$ & Brandle, Blackberry & Leaves & 154.05 & 72.15 & 34 & \\
\hline $\begin{array}{l}\text { Crataegus aronia (L.) DC. (Rosaceae) } \\
\text { (BERC-BX-C-0059) }\end{array}$ & Hawthorn, Azarole & Leaves & 106.5 & 69.83 & 33 & \\
\hline $\begin{array}{l}\text { Cupressus arizonica Greene } \\
\text { (Cupressaceae) }\end{array}$ & Arizona Cypress & Leaves & 126.13 & 68.33 & 32 & \\
\hline $\begin{array}{l}\text { Ruta chalepensis L. (Rutaceae) } \\
\text { (BERC-BX-C-0008) }\end{array}$ & Rue & Leaves & 41.3 & 21.93 & 30 & \\
\hline $\begin{array}{l}\text { Teucrium creticum L. (Lamiaceae) } \\
\text { (BERC-BX-C-0173) }\end{array}$ & Cretan Germander & Areal Parts & 52.4 & 19.8 & 29 & \\
\hline $\begin{array}{l}\text { Varthemia iphionoides Boiss. \& Blanche } \\
\text { (Asteraceae) (BERC-BX-C-0135) }\end{array}$ & Common Verthemia & Areal Parts & 94.3 & 45.58 & 29 & \\
\hline $\begin{array}{l}\text { Elaeagnus angustifolia L. } \\
\text { (Elaeagnaceae) (BERC-BX-C-0050) }\end{array}$ & Narrow-Leaved Oleaster & Leaves & 50.23 & 33.95 & 27 & \\
\hline $\begin{array}{l}\text { Origanum syriacum L. (Lamiaceae) } \\
\text { (BERC-BX-C-0026) }\end{array}$ & $\begin{array}{l}\text { Wild Thyme, Mother } \\
\text { Of Thyme }\end{array}$ & Areal Parts & 91.23 & 40.83 & 25 & \\
\hline $\begin{array}{l}\text { Euphorbia hierosolymitana Boiss. } \\
\text { (Euphorbiaceae) (BERC-BX-C-0170) }\end{array}$ & Spurge & Areal Parts & 42.53 & 18.9 & 21 & \\
\hline $\begin{array}{l}\text { Lantana camara L. (Verbenaceae) } \\
\text { (BERC-BX-C-0134) }\end{array}$ & Lantana & Areal Parts & 84.65 & 44.78 & 17 & \\
\hline $\begin{array}{l}\text { Thuja occidentalis L. (Cupressaceae) } \\
\text { (BERC-BX-C-0040) }\end{array}$ & Tree Of Life & Areal Parts & 71.98 & 42.38 & 12 & \\
\hline $\begin{array}{l}\text { Retama raetam (Forssk.) Webb } \\
\text { (Fabaceae) (BERC-BX-C-0043) }\end{array}$ & Retama, White Broom & Areal Parts & 99.48 & 72.7 & 8 & \\
\hline Ficus carica L. (Moraceae) (BERC-BX-C-0048) & Fig Tree & Leaves & 35.3 & 13.25 & 7 & \\
\hline
\end{tabular}

$30 \mu \mathrm{l}$ of PBS, and $150 \mu \mathrm{l}$ of diluted plant extract (at a concentration of $1 \mathrm{mg} / \mathrm{mL}$ ). The mixture was incubated for $3 \mathrm{~h}$ at $37^{\circ} \mathrm{C}$. After the incubation period, larvae were washed with PBS and centrifuged at $3000 \mathrm{rpm}$; this step was repeated three times. Artificial exsheathment was induced in vitro by adding a solution of sodium hypochlorite $(2 \% \mathrm{w} / \mathrm{v})$ and sodium chloride $(16.5 \% \mathrm{w} / \mathrm{v})$, diluted 1:300 in PBS, to the larval suspension. The kinetics of larval exsheathment process was determined by removing an aliquot containing about less than one-fifth of the larvae content at time intervals of $0,15,30,45$, and $60 \mathrm{~min}$ from exposure, and counting the number of 
exsheathed and ensheathed individuals under Olympus microscope CX31 $(400 \times)$. Counts were averaged within each time point.

\section{Minimum inhibitory concentration $\left(I C_{50}\right)$}

The minimum inhibitory concentration $\left(I C_{50}\right)$, which is defined as the amount of the extract necessary to decrease the larval exsheathment by $50 \%$, was determined by the regression between the percentage of exsheathment inhibition and concentration of the extracts $(\mathrm{mg} / \mathrm{mL})$ after $45 \mathrm{~min}$ incubation using Microsoft Excel Program 2010. Plant extract concentrations used were $1,0.5,0.25$, and $0.125(\mathrm{mg} / \mathrm{mL})$. PBS was used as a negative control.

\section{Statistical analyses}

The percentage of larval exsheathment in each plant extract and negative control was calculated as follow [38]:

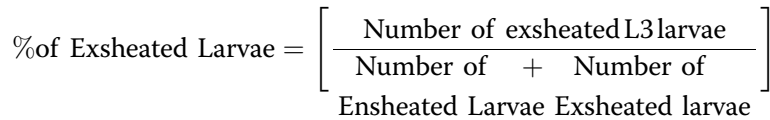

$$
\begin{aligned}
& \text { X } 100
\end{aligned}
$$

Values of semi-log slopes for the percentages of exsheathed larvae at each of the five time intervals were calculated and subjected to analysis of variance using the General Linear Model procedure of SAS (1989). For LEIA, the model comprised treatment with 50 levels (48 plant extracts $\times 1$ extraction method, and a PBS control).

\section{Results}

\section{Polyphenolic compounds and tannins}

Extraction yields ranged between 13 and 37\% depending on the plant species. The polyphenols concentration expressed as gallic acid equivalent are shown in Table 1 and Fig. 1. Total polyphenols levels in plant extracts were ranged from $18.9 \mathrm{mg} / \mathrm{g}$ GAE in Capparis spinosa leaves to $256.8 \mathrm{mg} / \mathrm{g}$ GAE in Rhus coriaria (Fig. 1, Table $1)$. On the other hand tannin levels were ranged from $0.35 \mathrm{mg} / \mathrm{g}$ GAE in C. spinosa leaves to $153.2 \mathrm{mg} / \mathrm{g} \mathrm{GAE}$ in Rosmarinus officinalis (Fig. 1, Table 1). It is worth noting that, although Capparis spinosa possess very low levels of total phenols and tannins it showed moderate exsheathment inhibition activity (46\%).

\section{Larval exsheathment inhibition assay (LEIA)}

The exsheathment of the infective third stage larvae (L3) of the mixed-species nematodes in the control groups was similar in all assays with more than $90 \%$ of exsheathment obtained after $60 \mathrm{~min}$ of incubation. In the tested plant extracts, after $3 \mathrm{~h}$ of contact with each plant extract, the percentage of exsheathment inhibition activity, obtained after $60 \mathrm{~min}$, ranged between 7 and 94\% where Rhamnus elatarnus, Rhamnus. palaestinus,
Pistacia palaestina, and Epilobium hirsutum showed the highest percentage of exsheathment inhibition activity of $94,89,84$, and $84 \%$, respectively (Table 1 ).

Out of the 48 plant extracts tested, 22 extracts showed exsheathment inhibitory activity of $\geq 50 \%$, where 17 exhibited LEIA of $\geq 30 \%-<50 \%$, and 9 plant extracts showed $<30 \%$ LEIA. The minimum inhibitory concentration $I C_{50}$ was calculated for the 14 plant extracts that showed $\geq 60 \%$ exsheathment inhibition activity (Table 1 ). Rhamnus alaternus extracts which possess relatively moderate levels of total phenols $(68.1 \mathrm{mg} / \mathrm{g})$ and tannins (46.35 $\mathrm{mg} / \mathrm{g}$ ), have shown the highest LEIA (94\%) and lowest $I C_{50}(0.02 \mathrm{mg} / \mathrm{mL}$, Table 1 and Fig. 2). On the other hand, some plant extracts showed low exsheathment inhibition activity despite having relatively high total phenolic content. Examples of those were: Crataegus aronia, (106.5 mg/g, 33\% LEIA), Cupressus arizonica (126.13, 32), Salvia fruticosa $(130.4,39)$, and Rubus sanctus $(154.1,34)$. However, no significant correlation was detected in this study between total phenolic or tannin contents and the \% of exsheathment inhibition activity.

\section{Discussion}

The eggs of parasitic strongyles are excreted in the animal faeces, hatch under suitable environmental conditions especially on pasture, producing two nonparasitical larval stages followed by a third-stage infective larvae (L3) that is ensheathed, i.e., retaining the shed cuticle from the previous moult for protection. L3 exsheathment is therefore a critical process in the life cycle, being a transitionary step from the free-living to the parasitic stages where its exsheathment inhibition is considered as a crucial stage of its control [39]. Using a two-species but steady population of parasitic nematodes (ca. 20\% Teladorsagia circumcinta and $80 \%$ Trichostrongylus colubriformis) was used in different works since both are found in the same animal [40].

In our results the Rhamnaceae family was represented by 4 species (Rhamnus alaternus, Rh. palaestinus, Ziziphus spina-christi, Z. sativa). The four species were among the 10 plant extracts with highest LEIA (Table 1). Different parts of the plants (leaves, aerial parts, seeds, fruits, and roots) belonging to the Rhamnaceae family are traditionally used in traditional medicine for the treatment of many illnesses such as inflammation, fever, insomnia, relieve pain, anthelmintic, weakness, hepatic disorders, obesity, urinary problems, muscle spasm and viral infections [41-44]. The Biological activity studies on these species revealed different medicinal features including antioxidant [45, 46], antimicrobial [46-48], anti-diabetic [49] and antifungal [50] activities. In addition, some of these species are grazed by animals including goats and sheep where polyphenol content may affect larval reproduction. 


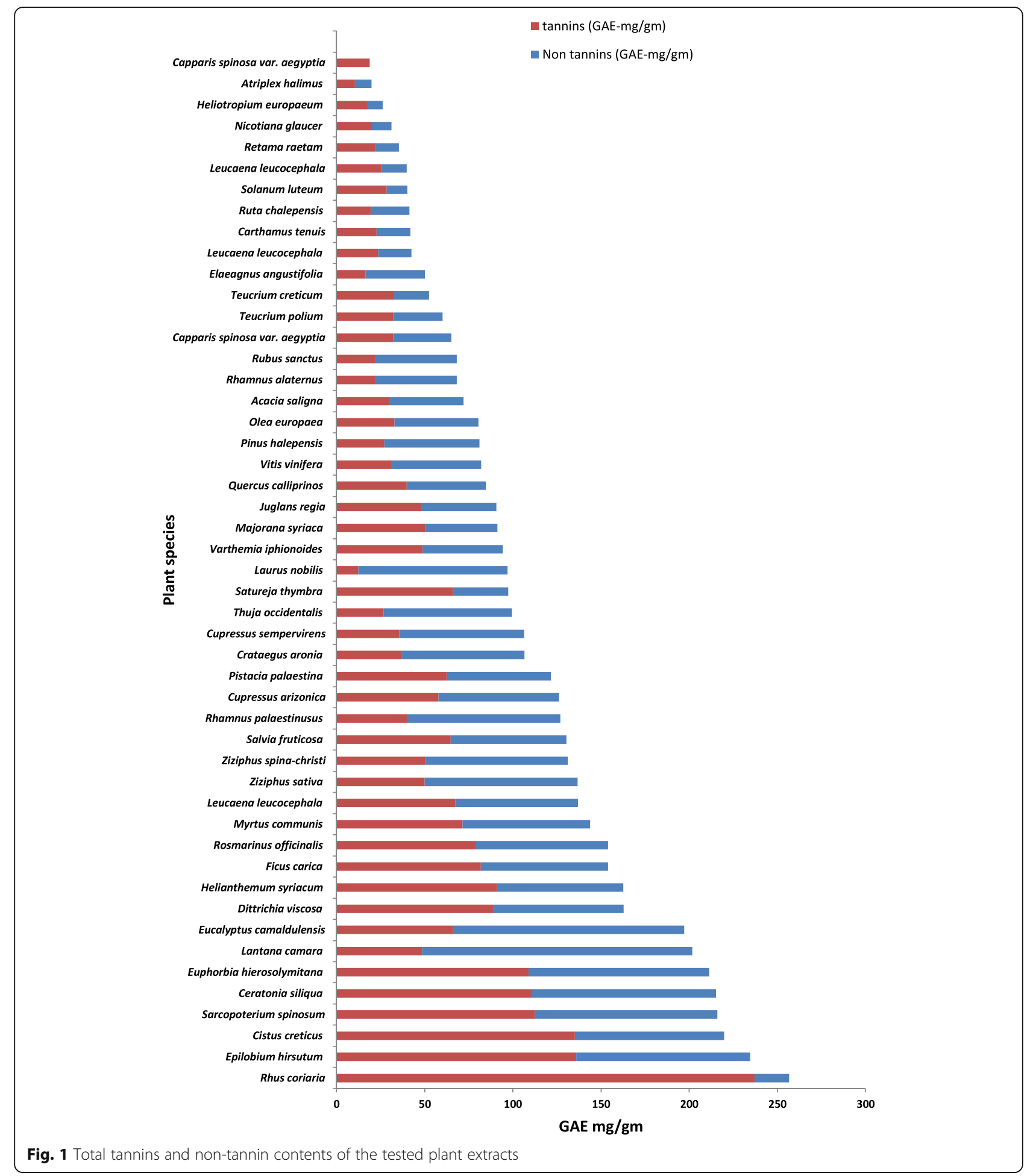

The Rhamnaceae species are known to produce a variety of characteristic secondary compounds including triterpenes, cyclopeptides alkaloids, benzylisoquinoline alkaloids (BIAs), and flavonoids [51]. Several studies have mentioned the importance of some phytochemicals like alkaloids, glycosides, terpenoids, tannins and flavonoids for showing anthelmintic activity of plant extracts [52, 53]. In this study we assume that the polyphenols and flavonoids were responsible for the anthelmintic activity of the Rhamnaceae plants which needs further investigation. We acknowledge that the value of the Folin-Ciocalteu to determine total phenolics is controversial. The extraction 

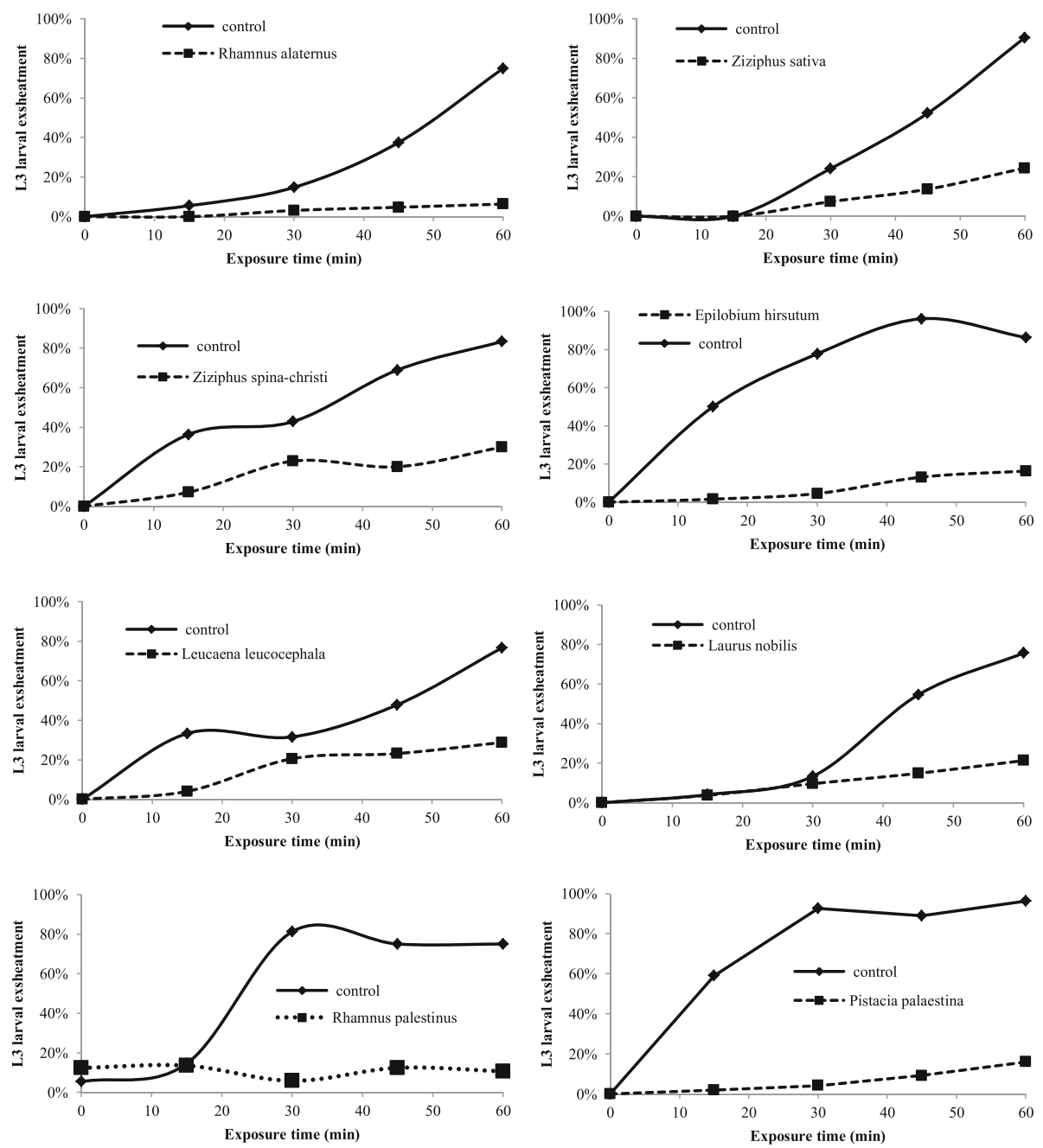

Fig. 2 Minimum inhibitory concentration $\left(/ C_{50}\right)$ of 8 plant extracts which exhibited $>70 \%$ exsheathment inhibition activity

of phenolic compounds from plant materials is influenced by different factors including: chemical structure, mineral nutrients, physiological processes, the extraction method, the solvent of extraction, the size of the particles forming samples, the time of sampling, extraction time, the conditions of storage as well as the presence of interfering compounds. Inorganic substances may also interact with Folin-Ciocalteu reagent giving varying results; in addition the structural features of phenolics are another parameter that should be considered when this assay is applied. However, it is the most straightforward measurement of phenolics and enables comparison of published data. In addition, we used PVP method in order to test total tannins out of the total phenols despite we know there are other methods to precipitate tannins from plant extracts such as alkaline ethanol [54].

Other plants which have shown LEIA $>70 \%$ included Epilobium hirsutum (84), Pistacia palaestina (84),
Laurus nobilis (79), and the leaves of Leucaena leucocephala (74).

Epilobium hirsutum has shown to possess a strong antioxidant and anticandidal activity [55], the plant contains polyphenols including steroids (especially $\beta$-sitosterol and its esters), tannins (gallic, protocatechuic, ellagic and pcoumaric acids) and flavonoids (in particular myricetin, isomyricetin, quercetin, and 5-quercetin-3-O- $\beta$-d-glucuronide) [56-58]. The isolated $\beta$-sitosterol from the methanolic extract of rhizomes of Hedychium spicatum has shown to possess a strong anthelmintic activity [59], thus the presence of $\beta$-sitosterol and tannins in E. hirsutum might explain its strong LEIA in this study.

Pistacia palaestina is used in traditional Palestinian herbal medicine for weight loss, and for the treatment of diabetes, urinary tract infections, kidney gallstone, and neuropathic pain [42]. In this study the plant exhibited strong LEIA (84\%) with $I C_{50}$ of $50 \mu \mathrm{g} / \mathrm{mL}$. A strong 
LEIA was also reported to $P$. atlantica of the same genus and family with very low $I C_{50}$ value of $3.5 \mu \mathrm{g} / \mathrm{mL}$ [18].

Laurus nobilis leaves are used as a spice for cooking purposes, the plant is used traditionally for the treatment of gastric diseases $[42,60]$. The plant leaves have been reported to possess wound healing, neuroprotective, antioxidant, antiulcerogenic, anticonvulsant, antimutagenic, antiviral, anticholinergic, antibacterial, and antifungal activities [61]. The anthelmintic activity of the plant can be associated with the presence of various sesquiterpene lactones which have been reported to be present in the plant [62]. Williams et al., [63], have attributed the anthelmintic activity of Cichorium intybus to its sesquiterpene lactones composition.

Leucaena leucocephala is often used as feed for livestock $[64,65]$. Leucaena possesses anthelmintic properties against both Haemonchus contortus [66] and Trichostrongylus colubriformis [67]. In our study the leaves of Leucaena have shown strong LIEA with $I C_{50}$ of $100 \mu \mathrm{g} / \mathrm{mL}$. The anthelmintic activity of the plant might be attributed to the protease inhibitor activity of the plant extracts [68]. Another study conducted in 2015 [69] performed a bio-guided fractionation of an aqueous extract of Leucaena leucocephala leaves using the egg hatch assay (EHA) to identify the phytochemicals present in fresh leaves with anthelmitic activity. The isolation procedures used led to the identification of an active fraction mainly composed of quercetin (82.21\%) and caffeic acid (13.42\%) which inhibited the egg hatching of Cooperia spp. by $90.49 \pm 2.8 \%$ of $(P<0.05)$.

Tannins are the most studied compounds for anthelmintic activity, however, some researchers have shown that the ethanolic extracts of Pistacia lentiscus still possess some anthelmintic activity remains after all tannins are bound by polyethyleneglycol [70]. In this study, some plants possess low levels of total phenols and tannin content, e.g., Nicotiana glauca, and Capporis spinosa, however these plants exhibited a moderate LEIA. Nicotiana glauca is an herbaceous plant with high toxicity due to its primary alkaloid anabasine content [71]. Although $N$. glauca possesses a low total phenolic and tannin contents the plant exhibited 50\% EIA, the anthelmintic activity of the plant might be attributed to its toxicity. However, the aqueous and methanolic extracts of plants of the same genus ( $N$. tabacum) have shown to possess anthelmintic activity when administrated orally for sheep naturally infected with mixed species of gastrointestinal nematodes [72].

Capparis spinosa fruits and leaves have been tested in this study for their LEIA, the tannin content ranged between $0.35 \mathrm{mg} / \mathrm{g}$ in leaves to $33 \mathrm{mg} / \mathrm{g}$ in fruits, with LEIA of 46 , and $49 \%$, respectively. The anthelmintic activity of ethanolic extract of root bark of $C$. spinosa was evaluated against earthworm, and the activity was found to be dose dependent [73]. Traditional medicine plays a vital role in the development of new drugs; a lot of plant-originated drugs in clinical medicine today were derived from traditional medicine [74-76]. Fifteen of the plant species analyzed in this study for their LEIA were mentioned to be used traditionally in ethnoveterinary medicine in Palestine for the treatment of several animal ailments [33]. Nine of these plants were reported to be used for the treatment of gastrointestinal diseases including diarrhea, and anthelmintic (Table 2). Our results

Table 2 Ethnoveterinary uses of plants used in Traditional Arabic Palestinian Herbal medicine (TAPHM) [33]

\begin{tabular}{|c|c|}
\hline Plant & Ethnoveterinary uses \\
\hline Ceratonia siliqua & $\begin{array}{l}\text { Nourishment, anthelmintic, scabies, eye inflammation, cleaning uterus, delay in giving birth, } \\
\text { diarrhea }\end{array}$ \\
\hline Crataegus aronia & Urine retention, constipation, inflammation, coccidia, pregnancy poisoning \\
\hline Cupressus sempervirens & Diarrhea \\
\hline Dittrichia viscosa & Expectorant, appetizer, flatulence, postpartum inflammation \\
\hline Eucalyptus camaldulensis & Fever \& malaria, flatulence, bees anaesthetization, diarrhea, scabies, inflammation \\
\hline Ficus carica & Ulcers, insects bites, constipation, nourishment \\
\hline Myrtus communis & Diarrhea, ulcers \\
\hline Olea europaea & $\begin{array}{l}\text { Eye diseases, bone fractures, anthelmintic, bruises, nourishment, injuries, scabies, colic, flatulence, } \\
\text { diarrhea }\end{array}$ \\
\hline Origanum syriacum & Flatulence, inflammation, Bites, cold, appetizer \\
\hline Rosmarinus officinalis & Animal fertility, arthritis, inflammation, constipation \\
\hline Salvia fruticosa & Appetizer, cleaning the uterus, colic, flatulence, poisoning, cold, diarrhea, satiety \\
\hline Solanum luteum & Dimples, scabies, injuries \\
\hline Teucrium capitatum & Diarrhea, colic, bleeding, scabies, flatulence \\
\hline Varthemia iphionoides & Colic, scabies diarrhea, fever, flatulence, pregnancy poisoning, udder infections \\
\hline Ziziphus spina-christi & Diarrhea, nourishment, anthelmintic, inflammation, carbuncles \\
\hline
\end{tabular}


support these ethnoveterinary studies and using these plants as grazing pasture or feed additives might contribute to a sustainable control of these nematodes in small ruminants.

\section{Conclusion}

Our results suggest natural resources that possess strong larval exsheathment inhibition activity with potential applications in animal therapeutics and feed. In our study the calculated $I C_{50}$ values for the most active extracts of Rhamnus alaternus, and Epilobium hirsutum were 20, and $30 \mu \mathrm{g} / \mathrm{mL}$, respectively. This is a strong indication of the high anthelmintic potential of these plants. Future studies are needed for screening in-depth phytochemical, clinical and possible studies on molecular mechanism of action. At the same time efforts should be made to normalize the plant extracts with potent anthelmintic activity and formulate best alternative herbal products to either substitute or supplement man-made drugs which are presently in use.

\section{Abbreviations}

DM: Dry matter; EIA: Exsheathment inhibition activity; GAE: Gallic acid equivalents; $I_{5}$ : Minimum inhibitory concentration; LEIA: Larval exsheathment inhibition assays; PBS: Phosphate buffered saline: PVP: Polyvinylpyrrolidone

\section{Acknowledgments}

Not applicable.

\section{Funding}

This research was supported in part by BARD-MARD Facilitating Grant Reference Number FG-9513-14 to the first author.

\section{Availability of data and materials}

The datasets used and/or analyzed during the current study are available from the corresponding author on reasonable request.

\section{Authors' contributions}

RMJ, and SYAZ carriedout laboratory work and data analyses. HA suggested the project, and revised the manuscript. AM supplied the parasites, suggested the project and contributed to conception and design. MSAS, RMJ, and SYAZ coordinated plant collection and prepared plant extracts. MSAS and RMJ wrote the manuscript. All authors read the final version of the manuscript. All authors read and approved the final manuscript.

\section{Ethics approval and consent to participate}

Not Applicable.

\section{Consent for publication}

Not Applicable.

\section{Competing interests}

The authors declare that they have no competing interests.

\section{Publisher's Note}

Springer Nature remains neutral with regard to jurisdictional claims in published maps and institutional affiliations.

\section{Author details}

'Biodiversity\& Environmental Research Center-BERC, Til, Nablus, Palestine. ${ }^{2}$ Kimron Veterinary Institute, Ministry of Agriculture and Rural Development, Jerusalem, Israel. ${ }^{3}$ The Institute of Applied Research, The Galilee Society,
P.O.B. 437, 20200 Shefa-Amr, Israel. ${ }^{4}$ Tel Hai College, Department of Environmental Science, 2208 Upper Galilee, Israel.

Received: 16 June 2017 Accepted: 30 October 2017

Published online: 03 November 2017

References

1. Knox MR, Torres-Acosta JFJ, Aguilar-Caballero AJ. Exploiting the effect of dietary supplementation of small ruminants on resilience and resistance against gastrointestinal nematodes. Vet Parasitol. 2006;139:385-93.

2. Roeber F, Jex AR, Gasser RB. Impact of gastrointestinal parasitic nematodes of sheep, and the role of advanced molecular tools for exploring epidemiology and drug resistance - an Australian perspective. Parasites \& Vectors. 2013;6:153. doi:10.1186/1756-3305-6-153.

3. Hoste H, Torres-Acosta JF. Non chemical control of helminths in ruminants: adapting solutions for changing worms in a changing world. Veterinary Parasitology. 2011;180(1-2):144-154.

4. Badran I, Abuamsha R, Aref R, Alqisi W, Alumor J. Prevalence and diversity of gastrointestinal parasites in small ruminants under two different rearing systems in Jenin District of Palestine. An - Najah Univ. J. Res. (N. Sc.). 2012; 26:1-18.

5. Hoste H, Sotiraki S, Landau SY, Jackson F, Beveridge I. Goat-nematode interactions: think differently. Trends in Parasitology. 2010;26(8):376-381.

6. Bellani L, Mantovani A, Mordenti A, Restani R. Socio-Economic Effects of Parasitic Disease of Animals. Veterinaria Italiana. 1974;11-12:501-520.

7. Jackson F, Coop RL. The development of anthelmintic resistance in sheep nematodes. Parasitol. 2000;120:95-107.

8. Papadopoulos E, Himonas C, Coles GC. Anthelmintic Resistance of Sheep and Goat Gastrointestinal Nematodes, Proceedings of the 7th Hellenic Veterinary Congress, Thessaloniki, 28 November-1 December, 1996, p. 149.

9. Gilleard J. Understanding anthelmintic resistance: the need for genomics and genetics. Int J Parasitol. 2006;36(12):1227-39.

10. Kaplan RM. Drug resistance in nematodes of veterinary importance: a status report. Trends Parasitol. 2004;20(10):477-81.

11. Wolstenholme AJ, Fairweather I, Prichard RK, von Samson-Himmelstjerna G, Sangster NC. Drug resistance in veterinary helminths. Trends Parasitol. 2014; 20(10):469-76.

12. Waller PJ, Thamsborg SM. Nematode control in "green" ruminant production systems. Trends Parasitol. 2004;20:493-7.

13. Kyriazakis I, Houdijk J. Immunonutrition: nutritional control of parasites. Small Rum Res. 2006;62:79-82.

14. Abushelaibi AA, Al Shamsi MS, Afifi H. Use of Antimicrobial Agents in Food Processing Systems. Recent Pat Food, Nutr Agric. 2012;4(1):2-7.

15. Cheng G, Hao H, Sh X, Wang X, Dai M, Huang L, Yuan Z. Antibiotic alternatives: the substitution of antibiotics in animal husbandry? Front Microbiol. 2014;13(5):217. https://doi.org/10.3389/fmicb.2014.00217.

16. Brunet $\mathrm{S}$, Jackson $\mathrm{F}$, Hoste $\mathrm{H}$. Effects of sainfoin (Onobrychis viciifolia) extract and monomers of condensed tannins on the association of abomasal nematode larvae with fundic explants. Int J Parasitol. 2008;38:783-90.

17. Hoste H, Jackson F, Athanasiadou S, Thamsborg SM, Hoskin SO. The effects of tannin rich plants on parasitic nematodes in ruminants. Trends Parasitol. 2006;22:253-61.

18. Azaizeh H, Halahleh F, Abbas N, Markovics A, Muklada H, Ungar ED, Landau SY. 2013. Polyphenols from Pistacia lentiscus and Phillyrea latifolia impair the exsheathment of gastro-intestinal nematode larvae. Vet Parasitol. 2013;191:44-50.

19. Barrau E, Fabre N, Fouraste I, Hoste H. Effect of bioactive compounds from sainfoin (Onobrychis viciifolia Scop.) on the in vitro larval migration of Haemonchus contortus: role of tannins and flavonol glycosides. Parasitology. 2005;131:531-8

20. Brunet S, Aufrère J, El Babili F, Fouraste I, Hoste H. The kinetics of exsheathment of nematode larvae is disturbed in presence of tannin-rich plant (sainfoin) both in vitro and in vivo. Parasitology 2007;134:1253-1262.

21. Molan AL, Faraj AM. The effects of condensed tannins extracted from different plant species on egg hatching and larval development of Teladorsagia circumcincta (Nematoda: Trichostrongylidae). Folia Parasitol. 2010;57(1):62-8

22. Lange KC, Olcott DD, Miller JE, Mosjidis JA, Terrill TH, Burke JM, Kearney MT. Effect of sericea lespedeza (Lespedeza cuneata) fed as hay, on natural and experimental Haemonchus contortus infections in lambs. Vet Parasitol. 2006;141:273-8. 
23. Heckendorn F, Haring DA, Maurer V, Senn M, Hertzberg H. Individual administration of three tanniferous forage plants to lambs artificially infected with Haemonchus contortus and Cooperia curticei. Veterinary Parasitology. 2007;146:123-34.

24. Minho AP, Bueno ICS, Louvandini H, Jackson F, Gennari SM, Abdalla AL. Effect of acacia tannin extract in the control gastrointestinal parasites in sheep. Anim Feed Sci Technol. 2008;147(1-3):172-81.

25. Minho AP, Filippsen LF, Francisco A, Amarante T, Abdalla AL. Efficacy of condensed tannin presents in acacia extract on the control of Trichostrongylus colubriformis in sheep. Ciência Rural. 2010;40(6):1360-5.

26. Hammond JA, Fielding D, Bishop SC. Prospects for plant anthelmintics in tropical veterinary medicine. Vet Res Commun. 1997;21(3):213-28.

27. Waller PJ, Bernes G, Thamsborg SM, Sukura A, Richter SH, Ingebrigtsen K, Höglund J. Plants as de-worming agents of livestock in the Nordic countries: historical perspective, popular beliefs and prospects for the future. Acta Vet Scand. 2001:42(1):31-44.

28. Kumarasingha R, Preston S, Yeo TC, Lim DSL, Tu CL, Palombo EA, Shaw JM, Gasser RB, Boag PR. Anthelmintic activity of selected ethno-medicinal plant extracts on parasitic stages of Haemonchus contortus. Parasites \& Vectors. 2016;9:187. https://doi.org/10.1186/s13071-016-1458-9.

29. Ali-Shtayeh MS, Jamous Rana M, Jamous RM. Complementary and alternative medicine use amongst Palestinian diabetic patients. Complementary Therapies in Clinical Practice. 2011a; https://doi.org/10. 1016/j.ctcp.2011.09.001

30. Ali-Shtayeh MS, Jamous Rana M, Jamous RM. Herbal preparation use by patients suffering from cancer in Palestine. Complementary Therapies in Clinical Practice. 2011b;17(04):235-40. https://doi.org/10.1016/j.ctcp.2011.06.002.

31. Ali-Shtayeh MS, Jamous Rana M, Jamous Rania M, Salameh NM. Complementary and alternative medicine (CAM) use among hypertensive patients in Palestine. Complement Ther Clin Pract. 2013;19(4):256-63.

32. Ali-Shtayeh MS, Jamous Rana M, Salameh NM, Jamous Rania M, Hamadeh AM. Complementary and alternative medicine use among cancer patients in Palestine with special reference to safety- related concerns. J Ethnopharmacol. 2016a;187:104-22.

33. Ali-Shtayeh MS, Jamous Rana M, Jamous RM. Traditional arabic Palestinian ethnoveterinary practices in animal health care: a field survey in the West Bank (Palestine). J Ethnopharmacol. 2016b;182:35-49.

34. Singh $R$, Kumar $P$, Singh $G$. Total phenolic, flavonoids and tannin contents in different extracts of Artemisia absinthium. J Intercultural. 2012;1(2):101-4.

35. Makkar HPS, Blümmel M, Borowy NK, Becker K. Gravimetric determination of tannins and their correlations with chemical and protein precipitation methods. J Sci Food Agric. 1993;61:161-5.

36. Van Wyk JA, Cabaret J, Michael LM. Morphological identification of nematode larvae of small ruminants and cattle simplified. Vet Parasitol. 2004;119:277-306.

37. Bahuaud D, Martinez-Ortiz de Montellano C, Chauveau S, Prevot F, TorresAcosta F, Fouraste I, Hoste H. Effects of four tanniferous plant extracts on the in vitro exsheathment of third-stage larvae of parasitic nematodes. Parasitology. 2006;132(4):545-54.

38. Oliveira LM, Bevilaqua CM, Macedo IT, Morais SM, Monteiro MV, Campello CC Ribeiro WL, Batista EK. Effect of six tropical tanniferous plant extracts on larval exsheathment of Haemonchus contortus. Rev Bras Parasitol. 2011;20:155-60.

39. Hertzberg $H$, Huwyler $U$, Kohler L, Rehbein S, Wanner M. Kinetics of exsheathment of infective ovine and bovine strongylid larvae in vivo and in vitro. Parasitol. 2002;125:65-70.

40. Azaizeh H, Mreny R, Markovics A, Muklada H, Glazer I, Landau SY. Seasonal variation in the effects of Mediterranean plant extracts on the exsheathment kinetics of goat gastro-intestinal nematode larvae. Small Ruminant Res. 2015;131:130-5.

41. Lee SM, Min BS, Lee C-G, Kim K-S, Kho YH. Cytotoxic triterpenoids from the fruits of Zizyphus jujube. Planta Med. 2003;69:1051-4.

42. Ali-Shtayeh MS, Jamous RM. Traditional Arabic Palestinian herbal medicine, TAPHM. Til, Nablus, Palestine: Biodiversity and Environmental Research Center, BERC; 2008.

43. Kirtikar KR, Basu B. Indian Medicinal Plants. 2nd ed. Periodical expert book Agency: Delhi; 1984

44. Han BH, Park MH. Folk Medicine: The Art and the Science. 6th ed. Washington, DC: The American Chemical Society; 1986.

45. Boussahel S, Dahamna S, Ruberto G, Siracusa L, Harzallah D. Phytochemical Study and antioxidant activities of leaves extracts from Rhamnus alaternus $\mathrm{L}$. Pharmacogn Commun. 2013;3:46-53.
46. Boussahel S, Speciale A, Dahamna S, Amar Y, Bonaccorsi I, Cacciola F, Cimino F, Donato P, Ferlazzo G, Harzallah D, Cristani M. Flavonoid profile, antioxidant and cytotoxic activity of different extracts from Algerian Rhamnus alaternus L. bark. Pharmacognosy Magazine. 2015;11Suppl 1:S102-9.

47. Elsadig Karar MG, Quiet L, Rezk A, Jaiswal R, Rehders M, Ullrich MS, Brix K, Kuhnert N. Phenolic profile and in vitro assessment of cytotoxicity and antibacterial activity of Ziziphus spina-christi Leaf Extracts. Medicinal Chemistry. 2016;6(3):143-56.

48. Moghadam MS, Maleki S, Darabpour E, Motamedi H, Nejad SMS. Antibacterial activity of eight Iranian plant extracts against methicillin and cefixime resistant Staphylococcous aureus strains. Asian J Trop Med 2010;3: 262-262.

49. Michel CG, Nesseem DI, Ismail MF. Anti-diabetic activity and stability study of the formulated leaf extract of Zizyphus spina-christi (L.) Willd with the influence of seasonal variation. J Ethnopharmacol. 2011:133:53-62.

50. Hadizadeh I, Peivastegan B, Kolahi M. Antifungal activity of nettle (Urtica dioica L.), colocynth (Citrullus colocynthis L. Schrad), oleander (Nerium oleander L.) and konar (Ziziphus spina-christi L.) extracts on plants pathogenic fungi. Pakistan J Biol Sci. 2009;12:58-63.

51. Alarcón J, Cespedes CL. Chemical constituents and biological activities of South American Rhamnaceae. Phytochem Rev. 2015;14:389. https://doi.org/ 10.1007/s11101-015-9404-6.

52. Acharya S, Dash GK, Brahman DK, Chhetri RR. Preliminary phytochemical investigation and anthelmintic activity of Acacia suma (Roxb) barks. International Research Journal of pharmacy. 2011;2(1):136-141.

53. Dash S, Das C, Sahoo DC. Phytochemical and anthelmintic screening of crud barck of Adenanthera pavovina Lim. Pharmacie Globalen (IJCP). 2010;2(10):1-4.

54. Xingchu GX, Li Y, Qu H. Removing tannins from medicinal plant extracts using an alkaline ethanol precipitation process: A case study of danshen injection. Molecules. 2014;19:18705-20.

55. Jamous RM, Abu Zaitoun SY, Husein Al, Qasem IBY, Ali-Shtayeh MS. Screening for Biological Activities of Medicinal Plants Used in Traditional Arabic Palestinian Herbal Medicine. Eur J Med Plants. 2015;9(1):1-13.

56. Barakat HH, Hussein SAM, Marzouk MS, Merfort I, Linscheid M, Nawwar MAM. Polyphenolic metabolites of Epilobium hirsutum. Phytochemistry. 1997;46(5):935-41.

57. Gruenwald J, Brendler T, Jaenicke C. PDR for herbal. New Jersey: Medical Economics Company; 2000.

58. Ivancheva S, Manolova N, Serkedjieva J, Dimov V, Ivanovska N. Polyphenols from Bulgarian medicinal plants with anti-infectious activity. Basic Life Sciences. 1992;59:717-28.

59. Sravani T, Paarakh PP, Shruthi SD. In silico and in vitro anthelmintic activity of B-sitosterol isolated from rhizomes of Hedychium spicatum Buch.-Ham. Ind J Narutal Prod Resour. 2014;5(3):258-61.

60. Dall'Acqua S, Cervellati R, Speroni E, Costa S, Guerra MC, Stella L, Greco E, Innocenti G. Phytochemical composition and antioxidant activity of Laurus nobilis L. leaf infusion. J Med Food. 2009;12(4):869-76.

61. Patrakar R, Mansuriya M, Patil P. Phytochemical and Pharmacological Review on Laurus nobilis. International Journal of Pharmaceutical and Chemical Sciences. 2277-5005;1 (2):595-602.

62. Fang F, Sang S, Kuang YC, Alexander G, Chi-Tang H, Robert TR. Isolation and identification of cytotoxic compounds from Bay leaf (Laurus nobilis). Food Chemistry. 2005;93:497-501.

63. Williams AR, Peña-Espinoza MA, Boas U, Simonsen HT, Enemark HL, Thamsborg SM. Anthelmintic activity of chicory (Cichorium intybus): in vitro effects on swine nematodes and relationship to sesquiterpene lactone composition. Parasitology. 2016;143(6):770-7.

64. Prasad JVNS, Korwar GR, Rao KV, Mandal UK, Rao GR, Srinivas I, et al. Optimum stand density of for wood production in Andhra Pradesh, Southern India. leucaena leucocephala Biomass Bioenergy 2011;35(1):227-235.

65. Pandey VC, Kumar A. leucaena leucocephala: an underutilized plant for pulp and paper production. Genet Resour Crop Evol. 2013;60(3):1165-71.

66. Oliveira LMB, Bevilaqua CML, Macedo ITF, Morais SM, Monteiro MVB, Campello CC, Ribeiro WLC, Batista EKF. Effect of six tropical tanniferous plant extracts on larval exsheathment of Haemonchus contortus. Rev Bras Parasitol Vet. 2011;20(2):155-60.

67. Cunha FR, Oliveira DF, Campos VP. Extratos vegetais com propriedades nematicidas e purificação do princípio ativo do extrato de Leucaena leucocephala. Fitopatol Bras. 2003;28(4):438-41. 
68. Soares AMS, Araújo SA, Lopes SG, Costa Junior LM. Anthelmintic activity of Leucaena leucocephala protein extracts on Haemonchus contortus. Revista Brasileira de Parasitologia Veterinária. 2015;24(4):396-401.

69. von Son-de Fernex E, Alonso-D'iaz MA, Mendoza-de Gives P, Valles-de la Mora B, Gonz' alez-' Cortazar M, Zamilpa A, Epigmenio CG. Elucidation of Leucaena leucocephala anthelmintic-like phytochemicals and the ultrastructural damage generated to eggs of Cooperia spp. Veterinary Parasitology. 2015; https://doi.org/10.1016/j.vetpar.2015.10.005

70. Landau S, Azaizeh H, Muklada H, Glasser T, Ungar ED, Baram H, Abbas N, Markovics A. 2010. Anthelmintic activity of Pistacia lentiscus foliage in two Middle Eastern breeds of goats differing in their propensity to consume tannin-rich browse. Veterinary Parasitology. 2010;173(2010):280-6.

71. Fekih Hassen M, Ben Sik Ali H, Jaoued O, Ayed S, Tilouche N, Gharbi R, Elatrous S. Severe Nicotiana glauca poisoning: a case report. J Clin Toxicol. 2014:4:-216. https://doi.org/10.4172/2161-0495.1000216.

72. Iqbal Z, Lateef M, Jabbar A, Muhammad G, Gilani HA. In vitro and in vivo anthelmintic activity of Nicotiana tabacum Linn. leaves against gastrointestinal nematods of sheep. Phytothr Res. 2006;20(1):46-8

73. Mali RG, Mahajan S, Patil KS. Anthelmintic activity of root bark of Capparis spinosa. Ind J Nat Prod. 2005;21:50-1.

74. Fabricant DS, Farnsworth NR. The value of plants used in traditional medicine for drug discovery. Environ Health Perspect. 2001;109:69-75.

75. Li-Weber M. New therapeutic aspects of flavones: The anticancer properties of Scutellaria and its main active constituents Wogonin, Baicalein and Baicalin. Cancer Treat Rev. 2009;35:57-68.

76. Yuan $\mathrm{H}, \mathrm{Ma} \mathrm{Q}$, Ye L, Piao G. The Traditional medicine and modern medicine from natural products. Molecules. 2016;21(5):559. https://doi.org/10.3390/ molecules21050559.

\section{Submit your next manuscript to BioMed Central and we will help you at every step:}

- We accept pre-submission inquiries

- Our selector tool helps you to find the most relevant journal

- We provide round the clock customer support

- Convenient online submission

- Thorough peer review

- Inclusion in PubMed and all major indexing services

- Maximum visibility for your research

Submit your manuscript at www.biomedcentral.com/submit 